\title{
Introduction: Borders in Translation and Intercultural Communication
}

\author{
Jonathan Evans and Helen Ringrow \\ University of Portsmouth
}

The question of borders has become more and more significant as we have been editing this special issue. On 23 June 2016, the United Kingdom voted to leave the European Union in a public referendum. While there are a number of complex reasons why a country might want to leave a large, supranational entity like the European Union, from abstract concepts like sovereignty to more concrete issues of membership fees, one of the issues that surfaced time and again in the public discourse was immigration and the need to control borders (Calamur). The UK's leaving Europe would mean that the land border between the Republic of Ireland and Northern Ireland becomes the only land border between the EU and the UK, posing numerous questions relating to the Northern Ireland peace process and the free movement between North and South (O'Toole). Donald Trump became the $45^{\text {th }}$ President of the United States of America in 2017. In his campaign, Trump advocated building a wall along the Mexico-USA border (and getting Mexico to pay for it) ("Immigration reform that will make America great again"). There remain ongoing tensions around European borders and refugees (Henley et al.), which have developed following the war in Syria, though were already present. These are not new issues: Étienne Balibar, writing in the early 1990s, discussed the problems of European racism and the question of the border in relation to Europe, while Gloria Anzaldúa explored the cultural meaning of the USA-Mexican border in her Borderlands/La Frontera, first published in 1987. Borders are in many ways problematized by globalization, but at the same time reinforced. As communications and transport technologies have developed, it has become easier for some things and some people to cross borders, while it has become more difficult for other things and other people.

This special issue aims to explore the notion of 'border' in relation to translation studies and intercultural communication. We want to go beyond the notion of translation as a form of border crossing, which Emily Apter has criticized as too simplistic (Against World Literature 100), while not dismissing the concept of 'border' from translation theory, as Anthony Pym ("Alternatives to Borders") and Edwin Gentzler ("Translation without Borders") do in different ways. We approach the idea of the border from both a political and disciplinary view. In other words, we are interested not only in borders between countries or other political entities (e.g. supranational organizations), but also in the way in which intellectual work is separated into distinct areas and practices, which do not necessarily come into contact. Translation studies has always been interdisciplinary (Holmes), sitting as it does between comparative literature, applied linguistics, cultural studies, media studies, sociology, anthropology and so on. The border crossing nature of the discipline is highlighted in the title of the recent collection Border Crossings: 
Translation Studies and other disciplines (Gambier and van Doorlsaer), which brought together scholars working on translation across a number of disciplines. Partially our interest comes from our own positions as academics working in translation studies and intercultural communication, two disciplines that share many research questions and hypotheses, but which do not necessarily connect institutionally as they might be housed in different departments.

In this introduction, we will discuss the notion of border and its position in current scholarship, before moving on to ways in which borders can be useful, focusing particularly on Walter Mignolo's notion of "border thinking". We then move onto how borders are viewed in both translation studies and intercultural communication. Following this, we suggest some possible directions for future research before introducing the papers in this special issue.

\section{Borders and Border Thinking}

Borders are an inevitable part of nation states, defining the territory of the state and regulating who enters and who leaves. Borders necessarily define an inside and an outside. Yet they are porous: they can be crossed, with passports and visas. ${ }^{1}$ As Balibar notes, borders have a "worldconfiguring" function (79): they define where one nation ends and another begins.

Borders are complex. They are in many senses both real and imaginary. They are real in the sense that they have effect on people trying to travel from one place to another. If one does not have the right paperwork then crossing a border becomes a significant problem. If you cannot understand the language of the border authority, then crossing the border can be very disorienting, especially if there is any sort of complication. Borders are also the place of work of many people, including those involved in various border authorities, but also the service industry around these border checkpoints. These checkpoints are the physical structures of borders where one has to follow a certain path, cross a certain line when asked. At the same time, borders are also not fixed: they move historically, following wars or diplomatic treaties. As Balibar notes, borders are no longer "unequivocally localizable" (91). More confusingly still, borders may not be at the edge of the country: they are often found within airports, which may, themselves, be located anywhere within a country. One might also include other forms of security check as a form of border (Balibar 84): for example, police checking identity papers of undocumented immigrants can lead to deportation.

Globalization has not eradicated borders, as thinkers such as Kenichi Ohmae suggested it might in the early 1990s. Indeed, as Yale Ferguson and Richard Mansbach argue, globalization has in some ways increased and intensified borders. Sandro Mezzadra and Brett Neilson also argue that borders are proliferating. Their focus is not only the traditional sort of political border that we have been discussing so far; they also include cultural and social aspects of borders (3). Balibar argues that borders are experienced differently depending on what class one belongs to as they (in the sense of geopolitical borders) effectively 'differentiate between individuals in terms of social class' (82; original emphasis). Building on this idea, Mezzadra and Neilson highlight that

\footnotetext{
${ }^{1}$ Somewhat like the limit, as discussed by Foucault: "a limit could not exist if it were absolutely uncrossable" (Aesthetics 73).
} 
the effect of political borders is to limit the movement of certain types of labour and regulate other types of labour (19-25, 95-130).

As part of their regulating function, borders are crossed. James Clifford reminds us that travel is a common human experience and the concept of culture as relating to one static place overlooks this crucial aspect (2-3). This insight comes from Clifford's work in and on anthropology, but is equally important to translation and intercultural communication, which focus on how people from different cultures interact. In a world full of travellers, borders control and regulate how we move around and who can or who cannot move from one space to another. It is precisely these movements of people (and ideas, capital and things) that contribute to the constant evolution of cultures. Translation is one way in which ideas can move across borders; intercultural communication implies that borders have already been crossed in some way. The existence of borders indicates that there is movement across them, which someone considers needs to be controlled.

Borders bring with them the idea of borderlands or, as Mezzadra and Neilson call it, "borderscape" (12-13). This is the area around the border and the various struggles around it. The area around the USA-Mexico border has been a fruitful source of thinking about borderlands (see e.g. Anzaldúa) and the hybridization of culture that takes places there, but there are many other locations where the presence of a border has become a significant feature of daily life. The experience of such borderlands can contain " $[\mathrm{h}]$ atred, anger and exploitation" (Anzaldúa 19), although there may be certain "compensations" to be had too (19). The Journal of Borderland Studies, which is the publication of the Association of Borderland Studies, contains much significant work dealing with the question of borders and borderlands. Contributions to the journal come from a variety of disciplines, highlighting the ways in which borders affect multiple aspects of life for those who live around them, including trade and media as well as movement.

Until this point, our main focus has been geopolitical borders (those between states), but there are also more abstract notions of border that affect, in many ways, how we perceive the world. Our secondary focus here will be disciplinary borders, which "establish the scientific division of labor" (Mezzadra and Neilson 16). Disciplinary borders, like physical borders, are both porous and policed. Ideas and works can cross the borders of disciplines and there are various forms of gatekeeping for entry into disciplines, from qualifications to peer-reviewers. There are also borders to what counts as knowledge for different groups, with certain ways of knowing or articulating knowledge deemed to be 'not really' knowledge: Michel Foucault calls these forms of knowledge "subjugated knowledges" (Society Must Be Defended 7). Another term, used by Judith Halberstam, is "local knowledges". As Halberstam notes, these knowledges might "be less efficient, may yield less marketable results, but may also, in the long term, be more sustainable" (9). Such forms of knowledge have been kept outside of the accepted forms of knowledge in education and schooling, but may lead to different ways of approaching ideas and objects. A classic example of such a form of local/subjugated knowledge is fan knowledge, which is too partisan for academia but at the same time shows an investment of time and 
thinking that is similar in many ways to academic study (Hills 16-20). ${ }^{2}$ Such local/subjugated forms of knowledge may also be forms of Indigenous knowledge or practices, which are being ignored or erased following colonization and the spread of Western forms of knowledge, or through globalization (Dabashi).

Thinking about borders can be theoretically productive, forcing us to question their function and who they serve. Mezzadra and Neilson discuss their work as a form of "border as method", where borders are "conceived of as a site of struggle" (18). They go on to argue that "borders are instrumental in producing space, labor power, markets, jurisdictions and a variety of other objects that converge on the production of subjectivity" (280). This sort of thinking requires us to ask how borders structure our lives and what this achieves, while at the same time questioning what is excluded by those borders. Other scholars have written about borderlands in ways in which they become productive sites: a place where different cultures intermingle, where different knowledges exist. Anzaldúa explores in Borderlands/La Frontera some of the contradictions of being from a border culture, such as wanting to defend that culture from outsiders and at the same time being critical of it (43). ${ }^{3}$ That experience she compares to "floundering in uncharted seas" (101), but at the same time this leads to flexibility, "a tolerance for contradictions, a tolerance for ambiguity" (101). Anzaldúa holds a positive hope for the future of the mestiza, one that could "[bring] us to the end of rape, of violence, of war" (102), although she also says that life at the border is "not a comfortable territory" (19).

There are opportunities to critique hegemonic forms of thought from a position on the border: Walter Mignolo argues for what he calls "border thinking." By this, he means a form of thinking that disrupts and counters hegemonic forms of thought, drawing from Foucault's notion of subjugated knowledges (Mignolo 19) and the work of scholars such as Darcy Ribiero, Edouard Glissant and Abdelkhebir Khatibi (among others) on postcolonial forms of knowledge. Mignolo's critique is based on the idea that Western forms of knowledge are local forms (i.e. they began in specific places and are based on specific practices) that have been elevated to global forms through European colonization (66). He argues that border thinking uses "dichotomous concepts" (85), for example, Marxism read through Amerindian languages, rather than conceiving of the world as a dichotomy (85). Border thinking, therefore, uses aspects of both hegemonic and non-hegemonic thought in order to overcome both. It recognizes the profound changes wrought upon societies by globalization and colonization, while also refusing to accept hegemonic reasoning as the only form. Mignolo's border thinking, then, shows the importance of the subjugated forms of knowledge, mentioned earlier, in the critique of colonial (and neo-colonial) thought and Eurocentrism. It also shows the theoretical importance of borders as places where cultures meet and (like Anzaldúa) the productive energies that can come from this. If borders have a "world configuring" function, working at and across borders can change the way the world is configured. This sort of thinking leads us to question who benefits from borders and their policing and offers productive routes into further research.

\footnotetext{
2 Thomas McLaughlin's concept of "vernacular theory", which is the theorizing of non-academic writers and thinkers, offers a similarly marginal form of knowledge.

${ }^{3}$ The form of Borderlands/La Frontera also explores various borders: it commingles English and Spanish (i.e. it codeswitches) and it mixes prose and poetry. It is also a book that is at the border of academia: it is critical but at the same time it is published by a non-academic press.
} 


\section{Borders in Translation Studies and Intercultural Communication}

In this section, we look at how borders are discussed in translation studies and intercultural communication, before suggesting some new directions for research. The word 'borders' is often used in titles of work in translation studies, for example in the title of Media Across Borders: Localizing TV, Film and Video Games (Esser et al.), the subtitle of Asia Through Art and Anthropology: Cultural Translation Across Borders (Nakamura et al.) or in the titles of articles such as "At the Borders Between Translation and Parody: Lydia Davis's Story about Marie Curie" (Evans). In many cases, the concept of borders is not really explored in the work, but the idea of translation as a way of crossing borders underpins this usage. Or "border" is used to describe a contact zone between two practices (e.g. translation and parody). The word "border" is therefore used in a number of instances when it is not central to the argument of the work. That said, the idea of crossing or working at borders is central to the idea of cultural mediation, as Michaela Wolf argues: "Cultural mediators work primarily at the transitions and fault lines" (245). Wolf's comments relate to the plurilingual space of the Habsburg Monarchy, where multiple languages and cultures interacted. As she notes, this multilingual environment can be read as 'an experimental laboratory' for the European Union (xvi), where there are similar challenges caused by the use of many languages. As translators work at the "transitions", Antonio Sousa Ribiero stresses that they can "occupy the spaces of articulation" and place themselves between different cultural forms and ways of making meaning. ${ }^{4}$

Translation can bring into relief the borders between cultures, as Wolf and Pym (Method) point out. In a sense, the act of translation is already an act of bordering: it is saying "this language is different from that one." As Naoki Sakai acknowledges, this can be supportive of nation building: the "imagined community" (Anderson) of a nation can be brought together by sharing a language. ${ }^{5}$ The translation of texts written in Chinese characters into Japanese in the eighteenth century was one way in which Japanese scholars sought to differentiate Japanese and Chinese in the past and extend the unity of Japanese into the past (Sakai, Translation and Subjectivity 2, "How Do We Count" 77-81). Sakai argues that this unity is illusory, given the use of Chinese characters by Japanese elites since the seventh century and the complexity of the relationships between what are now China and Japan in the following centuries, yet at the same time the translation allows a space for the distinction between Chinese and Japanese writing. Translation effectively posits both languages as unities (83), even when, in reality, they are not simple or singular. As such, for Sakai, translation is "not only a border crossing but also and preliminarily an act of drawing a border, of bordering" ("How Do We Count" 83; original emphasis). In a similar way, Joyce Liu and Nick Vaughn Williams argue that translation 'must be understood as a border economy involving inclusions and exclusions' (5) and find in translation the possibility of deconstructing binaries (especially the one between Europe and East-Asia). Translation here resembles the contradictory border position described by Anzaldúa.

\footnotetext{
${ }^{4}$ Here we are not looking at the literature on translation of 'border writing', e.g. chicano/a writing (see, for example, Manzanas; Gentzler, Translation and Identity 143-179), which also instrumentalizes the notion of border.

5 Though Sakai ("How Do We Count") criticizes the notion of a single language. See also Solomon for a development of this idea.
} 
There is also much work in translation studies about disciplinary borders. The difference between adaptation and translation has exercised many scholars, from Dryden onwards (see Chan 388 for a summary; see also Raw). This sort of theorizing is often designed to draw lines between acceptable forms of translation (for translation studies) and other intertextual practices. It is designed, therefore, to police the borders of the discipline, narrowing down what is acceptable to write about or to practise. Yet the practices of translation and adaptation are often very similar and difficult to separate out, especially in software localization, but also in the case of interlingual film remakes or drama translation. There are moves from both adaptation and translation studies to recognize such similarities: Linda Hutcheon, in her $A$ Theory of Adaptation, recognizes translation as a subset of adaptation (171) and André Lefevere has argued for the positioning of translation in a wider context of rewriting. The notion of the border between the disciplines remains though, as the question of where scholars are homed institutionally is at stake in the distinction between translation and adaptation. A more recent example, which is aimed more at building dialogue across disciplines, is the already mentioned Border Crossings (Gambier and van Doorlsaer): this volume contains contributions co-written by scholars working on translation from within translation studies and in other disciplines. A further use of borders in relation to translation appears in the work of Margaret Rodgers, who not only explores the use of borders in relation to the discipline, but also investigates what are the borders of texts, terms and the borders between specialized and non-specialized translation (43-80).

Few scholars have actively written about translation and interpreting at border points (e.g. at the entry point to a country). Apter's critique of the use of "border-crossing" in writing about translation, which is developed in her Against World Literature and the article "Translation at the Checkpoint," is one place where actual borders and the difficulty of crossing them is addressed, though Apter does not investigate actual instances of translation or interpreting at borders. Rather, Apter asks the reader to question the metaphorical usage of both borders and translation ("Translation" 59) as this wider usage overlooks the real effects of borders (such as exclusion from a country, detention, etc.) and the difficulties of translation. Language usage at borders is a political issue as it makes passage easier for some speakers than others-not speaking the language of the border patrol is going to make crossing the border more complex as instructions cannot be understood. While border paperwork may be available in multiple languages and there may even be access to interpreters, this cannot be provided for every language.

Much of the early research and training in the field of intercultural communication had a clear focus on border crossings, with experts giving advice to (predominantly) North American military personnel (Geldard and Bouman; Kraemer); corporate business people (Barnlund; Hall and Hall); and religious missionaries (Cooke, Mayers) to prepare for work and life in a new cultural and linguistic context. In this sense, communication across borders was far from neutral, as it had the objective of gaining some kind of advantage over the foreign 'Other" through this teaching of strategies to smoothly facilitate border crossing (Piller 29-30). The business context of intercultural communication has remained salient, which can be most evidently seen in the work of Geert Hofstede. Hofstede's research in intercultural communication, in which he outlines six dimensions of national culture to facilitate cross-cultural comparisons based on his

${ }^{6}$ Whether the foreign 'Other' benefitted too was certainly debatable in some contexts. 
research with IBM employees, has continued to remain extremely popular in global business training contexts. This popularity is in spite of sustained critiques of his work from intercultural communication scholars, particularly in terms of methodology, conceptualizations of culture, and a Western bias (Piller, Holliday). The distillation of national cultures into six features which one can compare and contrast is arguably appealing to cross-cultural trainers, but may not always adequately capture complicated realities.

More contemporary research into intercultural communication has questioned both the very existence and the often-assumed rigidity of 'nation' and 'borders' (which had appeared axiomatic in earlier research in this field), in addition to a sometimes quite artificial separation of language and culture, with a lack of consideration of translation issues (Holliday 66). Adrian Holliday's work in particular has consistently argued for conceptualizations of culture which are fluid, complex, and ever-changing, in contrast to the more essentialist-leaning Hofstede tradition. A more productive way of viewing culture should also consider how culture is called into play by various individuals and groups as national identity markers: even if the borders of nations are to some extent a creation, they have real-life consequences. Holliday (15) emphasizes that although people are influenced to greater or lesser degrees by their national background, they possess cultural traits that can help them to cross different divides. Within the field of intercultural communication research, disciplinary boundaries are often crossed as the field intersects with a range of other disciplines including anthropology, sociology, psychology, and, of course, translation studies. ${ }^{7}$ Juliane House and Jens Loenhoff discuss this "special relationship" between translation studies and communication studies, especially within the realm of intercultural communication. Language is unequivocally embedded in cultural contexts and the very act of translation itself can be conceptualized as a type of intercultural communication (House and Loenhoff 101, 105). The required reflection in translation to achieve functional equivalence further strengthens the potential for translation to enhance intercultural cooperation (House and Loenhoff 104-105). Translation studies as a discipline is relevant to intercultural communication because of its focus on the most appropriate ways to cross linguistic borders in multiple domains (House and Leonhoff 107; see also House). The relationship between theory and practice is significant in both communication studies and translation studies. Despite these and many more points of contact, House and Leonoff lament the overall absences of fruitful cross-disciplinary activities between these two spheres, and call for researchers to foster these important connections. ${ }^{8}$ The increasing significance of translations from and into English as a lingua franca (Taviano; House) may be one area in which translation studies and communication studies could work collaboratively, drawing together translational and communicative action (House 112).

There are a number of directions that our survey suggests for research on the relationship between translation, intercultural communication and borders. Not least is the importance of work on language usage, translation and interpreting at national borders. It is important to look at empirical data to see how this takes place and what sorts of practices are encouraged or discouraged. That said, we recognize that there may be difficulties in accessing

${ }^{7}$ Jane Jackson provides a good overview of the interdisciplinary nature of much intercultural communication work in Chapter 2 of Language and Intercultural Communication.

${ }^{8}$ The authors give the example of community interpreting as an area where cross-disciplinary synergy could be achieved. 
such data or undertaking observations at borders. Furthermore, following in the wake of Sakai and Pym, the study of how translation creates borders needs to be expanded. In what ways is translation instrumentalized to exclude or include groups of people? There are also questions of how concepts of translation (as equivalence or as a professional activity) exclude other translational activities that deserve to be studied from the purview of translation studies, asking how vernacular theories of translation can be incorporated into more scholarly theory for a more detailed understanding of how translation is conceived of and experienced by people who are not professional translators or scholars. This opening up of the discipline will not destroy the borders between academia and everyday life, but allow a more porous movement of ideas between them.

\section{Articles in this Issue}

This special issue explores the concept of border crossing in a range of diverse and pertinent contexts. One such domain is moving image. Alida Payson and Mirona Moraru critically examine the filmic representation of migrants in the border spaces of Britain in the film Dirty Pretty Things, which takes on new salience in ever-growing debates about immigration and free movement sparked by Brexit. The authors argue that the accents and cultural illusions of the multilingual cast, some of whom learned to speak English for the film, form a kind of domesticated translation which highlights the act of border crossing. Dubbing can also be viewed as a way of crossing borders on screen. In her article on dubbing practices, Frédérique Brisset explores the act of dubbing a film as perhaps a more 'holistic' way to translate text, plot, dialogue and so on, without the arguably more explicit use of subtitles. The author discusses the potential effects of dubbing in a range of cinematic contexts.

Crossing borders in translation can take on different kinds of meanings depending on the source and target languages involved. Richard Mansell discusses the implications of this for the growing industry of translated literature in the UK. The increasingly popularity of translated texts in the UK has led to a new tendency for agents to commission their own translations of the source text before translation rights have been sold. Agents may therefore function as "gatekeepers" to the texts, having control over what is allowed to cross. When smaller languages are involved in these kinds of crossings, there may of course be different power dynamics at play here. David ar Rouz explores these power dynamics using examples of translations to and from Breton. He emphasizes the importance of negotiation to facilitate the crossing of both sociocultural and linguistic borders. These borders can in some instances seemingly be traversed more quickly and easily with the use of translation technology. Tomáš Svoboda's article aims to highlight current developments in machine translation, drawing attention to the challenges involved in its widespread use. The author suggests future developments in machine translation may continue to aid border crossing. Taken together, these articles show the diversity of approaches possible when discussing borders in translation and the vibrancy of the topic. We hope that they will lead readers to investigate further. 


\section{REFERENCES}

Anderson, Benedict. Imagined Communities: Reflections on the Origin and Spread of Nationalism. Revised ed., Verso, 1991.

Anzaldúa, Gloria. Borderlands/La Frontera: The New Mestiza. 2nd ed., Aunt Lute Books, 1999.

Apter, Emily. Against World Literature. Verso, 2013.

- "Translation at the Checkpoint." Journal of Postcolonial Writing, vol. 50, no. 1, 2014, pp. $56-74$.

Balibar, Étienne. Politics and the Other Scene. Translated by Christine Jones et al, Verso, 2002.

Barnlund, Dean. C. Communicative Styles of Japanese and Americans: Images and Realities. Wadsworth, 1989.

Calamur, Krishnadev. "Will Brexit Actually Curb Immigration to the U.K.?" The Atlantic. 29 June 2016. www.theatlantic.com/news/archive/2016/06/brexit-migration/489014/ Accessed 28 July 2016.

Chan, Leo Tak-Hung. "At the Borders of Translation: Traditional and Modern(ist) Adaptations, East and West". Meta, vol. 54, no. 3, 2009, pp. 387-400.

Clifford, James. Routes: Travel and Translation in the Late Twentieth Century. Harvard UP, 1997.

Cooke, Gerald. As Christians Face Rival Religions: An Interreligious Strategy for Community without Compromise. Association Press, 1962.

Dabashi, Hamid. Can Non-Europeans Think? Zed Books, 2015.

Esser, Andrea, et al., editors. Media Across Borders: Localising TV, Film and Video Games. Routledge, 2016.

Evans, Jonathan. “At the Borders between Translation and Parody: Lydia Davis's Story about Marie Curie”. TTR, vol. 25, no. 2, 2012, pp. 167-191.

Ferguson, Yale H. and Richard W. Mansbach. Globalization: The Return of Borders to a Borderless World? Routledge, 2012.

Foucault, Michel. Aesthetics: Essential Works of Foucault 1954-1984. Vol. 2. Edited by James D. Faubion, Penguin, 2000.

Society Must Be Defended. Translated by David Macey, Penguin, 2003. 
Gambier, Yves and Luc van Doorslaer, editors. Border Crossings: Translation Studies and other disciplines. Benjamins, 2016.

Gentzler, Edwin. Translation and Identity in the Americas: New Directions in Translation Theory. Routledge, 2008.

- "Translation without Borders". Translation: A Transdisciplinary Journal. N.d. http://translation.fusp.it/articles/translation-without-borders Accessed 4 August 2016.

Geldard, F.A. and Bouman, M.A, editors. NATO Symposium on Communication Processes, W ashington, D.C. 1963. Macmillan, 1965.

Halberstam, Judith. The Queer Art of Failure. Duke UP, 2011.

Hall, Edward. T. and Mildred Reed Hall. Hidden Differences: Doing Business with the Japanese. Doubleday, 1987

Henley, Jon, et al. "Refugee Crisis: European Leaders Demand Urgent Support for Greece." The Guardian. 1 March 2016. www.guardian.co.uk Accessed 28 July 2016.

Hills, Matt. Fan Cultures. Routledge, 2002.

Hofstede, Geert H. Culture's Consequences: Comparing Values, Behaviors, Institutions, and Organizations across Nations. 2nd ed., Sage, 2001.

Holliday, Adrian. Intercultural Communication and Ideology. Sage, 2011.

Holmes, James S. Translated! Papers on Literary and Translation Studies. 1994. Foreign Language Teaching and Research Press, 2006.

House, Juliane. "English as a Lingua Franca and Translation". The Interpreter and Translator Trainer, vol. 7, no. 2, 2013, pp. 279-298, doi: 10.1080/13556509.2013.10798855.

House, Juliane and Jens Loenhoff. "Communication Studies and Translation Studies: A Special Relationship". Border Crossings: Translation Studies and Other Disciplines, edited by Yves Gambier and Luc van Doorslaer, Benjamins, 2016, pp. 97-116.

Hutcheon, Linda. A Theory of Adaptation. Routledge, 2006.

"Immigration Reform that Will Make America Great Again." wwm.donaldjtrump.com. N.d. http://assets.donalditrump.com/Immigration-Reform-Trump.pdf Accessed 6 July 2017.

Jackson. Jane. Introducing Language and Intercultural Communication. Routledge, 2014. 
Kraemer, A. J. The Development of Cultural Self-Awareness: Design of a Program of Instruction [United States. Dept. of the Army. Office, Chief of Research and Development. NATO Conference on Special Training for Multilateral Forces]. George Washington University, Human Resources Research Office, 1969

Lefevere, André. Translation, Rewriting and the Manipulation of Literary Fame. Routledge, 1992.

Liu, Joyce C.H. and Nick Vaughn Williams. "Introduction: Translating Borders, Deconstructing "Europe/East Asia"”. European-East Asian Borders in Translation, edited by Joyce C.H. Liu and Nick Vaughn Williams, Routledge, 2014, pp. 1-11.

Manzanas, Ana María, editor. Border Transits: Literature and Culture across the Line. Rodopi, 2007.

Mayers, Marvin K. Christianity Confronts Culture: A Strategy for Cross-cultural Evangelism. Zondervan, 1974.

Mignolo, Walter D. Local Histories/Global Designs: Coloniality, Subaltern Knowledges, and Border Thinking. Princeton UP, 2000.

McLaughlin, Thomas. Street Smarts and Critical Theory: Listening to the Vernacular. U of Wisconsin P, 1996.

Mezzadra, Sandro and Brett Nielson. Border as Method, or, the Multiplication of Labor. Duke UP, 2013.

Nakamura, Fuyubi, et al., editors. Asia through Art and Anthropology: Cultural Translation across Borders. Bloomsbury, 2013.

Ohmae, Kenichi. The Borderless World: Power and Strategy in the Interlinked Economy. Harper, 1990.

O’Toole, Emer. "Ireland Faces Partition Again. Preserving the Peace is Critical." The Guardian. 26 June 2016. www.guardian.co.uk Accessed 28 July 2016.

Piller, Ingrid. Intercultural Communication: A Critical Introduction. Edinburgh UP, 2011.

Pym, Anthony. "Alternatives to Borders in Translation Theory." Athanor, vol. 4, 2001, pp. 172 82. Method in Translation History. St Jerome, 1998.

Raw, Laurence (ed.). Translation, Adaptation and Transformation. Bloomsbury, 2012.

Rodgers, Margaret. Specialised Translation: Shedding the 'Non-Literary' Tag. Palgrave Macmillan, 2015. 
Sakai, Naoki. "How Do we Count a Language? Translation and Discontinuity". Translation Studies, vol. 2, no.1, 2009, pp. 71-88.

Translation and Subjectivity: On "Tapan" and Cultural Nationalism. U of Minnesota P, 1997.

Solomon, Jon. "The Transnational Study of Culture and the Indeterminacy of People(s) and Language(s)". The Trans/National Study of Culture: A Translational Perspective, edited by Doris Bachmann-Medick, De Gruyter, 2014, pp. 69-92.

Sousa Ribiero, António. “The Reason of Borders or a Border Reason? Translation as a Metaphor for our Times”. Eurozine. 8 Jan 2004. www.eurozine.com/the-reason-of-borders-or-a-borderreason/ Accessed 6 July 2017.

Taviano, Stefania. "English as a Lingua Franca and Translation". The Interpreter and Translator Trainer, vol. 7, no. 2, 2013, pp. 155-167, doi: 10.1080/13556509.2013.10798849.

Wolf, Michaela. The Habsburg Monarchy's Many-Languaged Soul: Translating and Interpreting, 1848-1918. Translated by Kate Sturge, Benjamins, 2015. 